\title{
REFLECTING CRITICAL INCIDENT AS A FORM OF ENGLISH TEACHERS' PROFESSIONAL DEVELOPMENT: AN INDONESIAN NARRATIVE INQUIRY RESEARCH
}

\author{
Alberik Ryan Tendy Wijaya, Paulus Kuswandono \\ Sanata Dharma University, Yogyakarta, Indonesia \\ (kus@usd.ac.id)
}

Received: $18^{\text {th }}$ July 2018; Revised: $25^{\text {th }}$ October 2018; Accepted: $28^{\text {th }}$ Desember 2018

\begin{abstract}
Amidst the rapid development of English teaching, teacher's professional development (TPD) is crucial for English teachers. It has been discussed in the TESOL Summit 2018 in Jakarta that the teachers demanded a TPD approach which facilitates them in sharing professional experiences with other teachers. This qualitative research would like to investigate the effectiveness of reflection with critical incident theory (CIT) framework as a form of TPD which many studies have found effective to fulfil that demand and yet, rarely discussed in the context of Indonesia. Based on the reviewed literature, this research applied guided reflection and interview to gather the data. The gathered data were then analysed using open-, axial-, and selective coding. From the triangulated data, five themes related to TPD were extracted. One theme is dedicated to discussing two unique cases. Overall, by reflecting their critical incidents, all of the participants could understand their experience deeper and thus, making it meaningful. Therefore, this research suggests that the utilization of reflection using CIT framework must be investigated further in a bigger scope with bigger participants and more frequencies of reflection.
\end{abstract}

Keywords: teacher's professional development; reflection; critical incident

\begin{abstract}
ABSTRAK
Di tengah pesatnya perkembangan pengajaran bahasa Inggris, pengembangan profesionalisme guru (TPD) penting bagi guru Bahasa Inggris. Telah didiskusikan dalam TESOL Summit 2018 di Jakarta bahwa para guru menginginkan sebuah pendekatan TPD yang memfasilitasi mereka untuk berbagi pengalaman profesional dengan guru lainnya. Penelitian kualitatif ini ingin menginvestigasi keefektifan refleksi dengan kerangka teori peristiwa kritis (CIT) sebagai bentuk TPD yang mana banyak studi telah menemukan keefektifan untuk memenuhi permintaan tersebut, akan tetapi jarang didiskusikan di dalam konteks Indonesia. Berdasarkan tinjauan pustaka, penelitian ini mengaplikasikan refleksi terpandu dan wawancara untuk mengumpulkan data. Data yang telah terkumpul dianalisis dengan menggunakan open-, axial-, dan selective coding. Dari data yang telah ditriangulasi, terekstrak lima tema terkait TPD. Satu tema didedikasikan untuk mendiskusikan dua kasus unik. Secara keseluruhan, dengan merefleksikan peristiwa kritis, semua partisipan mampu memahami pengalaman mereka secara lebih mendalam dan oleh karenanya, membuat pengalaman tersebut bermakna. Maka dari itu, penelitian ini menganjurkan agar penggunaan refleksi dengan kerangka CIT diinvestigasi lebih lanjut dalam skala yang lebih besar dengan lebih banyak partisipan dan frekuensi refleksi yang dilakukan.
\end{abstract}

Kata kunci: pengembangan profesionalisme guru; refleksi; peristiwa kritis

How to Cite: Wijaya, Alberik R. T., Kuswandono, P. (2018). Reflecting Critical Incident as a Form of English Teachers' Professional Development: an Indonesian Narrative Inquiry Research. IJEE (Indonesian Journal of English Education), 5(2), 101-118. doi:10.15408/ijee.v5i2.10923

IJEE (Indonesian Journal of English Education), 5 (2), 2018, 101-118

P-ISSN: 2356-1777, E-ISSN: 2443-0390 | DOI: http://dx.doi.org/10.15408/ijee.v5i2.10923

This is an open access article under CC-BY-SA license (https://creativecommons.org/licenses/by-sa/4.0/) 


\section{INTRODUCTION}

Teacher's professional development (TPD) has become a trending topic amidst international researchers (Körkkö, Kyrö-Ämmälä, \& Turunen, 2016; Nauman, 2017) because teachers are seen as the foundation of education (Varghese, Morgan, Johnston, \& Johnson, 2005). Developing teachers means developing education (Körkkö et al., 2016; Putri \& Imaniyati, 2017). However, the challenge is that TPD is affected by many aspects, such as personal, policy, and cultural aspects. Furthermore, education itself is dynamically reforming and for teachers to keep pace with the reform is of paramount importance (Nauman, 2017); this notion emphasises the critical need of a contextual professional development. Therefore, even though many researchers have explored it, continuous research on the TPD in various contexts is needed (Nauman, 2017).

Acknowledging the importance of this particular topic, some Indonesian researchers have contributed to this topic by bringing TPD to Indonesian context (e.g. Mustofa, 2007; Putri \& Imaniyati, 2017; Rahman, 2016; Widodo \& Riandi, 2013; Yuwono \& Harbon, 2010). In 2007, Mustofa laid some important aspects of TPD in Indonesia and also problems surrounding it. One of the key points he argued is that teachers must be more independent in developing themselves professionally. This notion is supported by Widodo and Riandi's (2013) statement in which "teachers are unlikely to participate in TPD unless it is formally required and financial support is provided" (p. 389). On the other hand, Yuwono and Harbon (2010, p. 147) pointed out that teachers in Indonesia were working alone with little support from the government and even colleagues themselves. Support from the government and/ or colleagues is as important as the teacher's own willingness in ensuring the effectiveness of TPD. The combination of both is crucial for Indonesian English teachers as they need to keep themselves relevant to the relatively dynamic development of English curriculum in Indonesia (Hawanti, 2014; Marcellino, 2008; Wiyono, 2017).

However, the conventional ways of TPD provided in Indonesia (Sari, 2012) do not exactly contribute positively to these problematic challenges. It has been discussed further by English teachers in TESOL summit Jakarta which was held on 4 February 2018 that most of the time, TPD in Indonesia is not based on English teacher's needs as it is using the conventional top-down approach. Therefore, during the summit, several types of TPD based on English teachers' needs were identified by the English teachers themselves. One of those types that are perceived as effective is sharing professional experiences.

Those types - according to empirical studies - can be facilitated 
through reflection (Kelly \& Cherkowski, 2015; Sari, 2012), especially by the use of critical incident theory (CIT) as a framework (Farrell, 2013; Hall \& Townsend, 2017). CIT invites the teachers to tell about and reflect on their most memorable experiences, both positive and negative (Farrell, 2013). By telling those stories and reflecting on their experiences with other people, teachers can acquire a deeper, more meaningful understanding of those experiences which ultimately could develop them even farther. Yet, as good as it might sound, reflection itself is not yet exhaustively explored in the context of Indonesia, let alone the CIT framework. Accordingly, Indonesian TPD and reflection must first be reviewed, followed by reflection using CIT framework.

TPD is prominent for teachers, especially English teachers, in developing themselves to reduce the gap between them and the dynamic curriculum in education (Nauman, 2017; Patton, Parker, \& Pratt, 2013). This is because TPD itself can be seen as "teachers' learning, how they learn to learn and how they apply their knowledge in practice to support pupil learning" (Postholm, 2012, p. 406). In order to be a professional teacher, one must learn to develop one's professional capital. This is further explained by Patton, Parker and Pratt (2013) that as it is "composed of a combination of human, social, and decisional capital, professional capital is the asset of teachers making decisions in complex situations with collective responsibility, openness to feedback, and a willing transparency" (p. 441). This asset is very important for teachers to have and develop as it is the most important element to adapt efficiently to dynamic changes and challenges in education. Not only do the teachers need to have knowledge and ability, but they must be able to adapt - willing to forget their prior, old knowledge and learn new, actual knowledge.

As teachers adapt to the educational needs, TPD itself is shifting its focus to not just highlight teachers' cognition, but also their emotion (Golombek \& Doran, 2014). Teachers' emotion - or feeling - is now considered to have a strong impact on teaching and learning processes in a classroom and also the development of the teachers themselves (Golombek \& Doran, 2014). All of this is in line with the needs of Indonesian English teachers, which are to chat and share the experience with people - not just from a cognitive perspective but also from an emotional perspective. One that is certain is that people need to talk to and to be heard and noticed by other people; this is one of the basic needs of humans including teachers. Thus, many TPD tools are developed to accommodate this need; one of them is the reflection.

As a mean of TPD, reflection has gained its popularity (Curtis et al., 2015; Golombek \& Doran, 2014; Killeavy \& Moloney, 2010). Reflection itself can be 
defined as a tool of elaborating one's experience (Killeavy \& Moloney, 2010). They give further corroboration in which "Reflection can be understood as a process of internal dialogue facilitated by thinking or writing and through an external dialogue and reflection together with others" (Killeavy \& Moloney, 2010, p. 1071). This method is powerful not only because it is a very effective technique of sharing and gathering experience, but it is also making the experience meaningful (Kuswandono, 2014). By reflecting on their experience, people will be able to use the internalised experience to guide them through difficult times.

Furthermore, it is also teacher-centred as it comes from within the teachers themselves - comes from their experience; like what teachers need (Patton et al., 2013). As seen from those notions, many things can be achieved through reflection when it is used for TPD, like stabilizing teacher's cognition, emotion, and activity (Golombek \& Doran, 2014), understanding teacher's experience to reduce gaps in education (Kelly \& Cherkowski, 2015), and most importantly, making the experience meaningful which develops teacher professionally (Killeavy \& Moloney, 2010). Thus, it can be inferred that reflection is one of the most effective tools in developing teacher professionally. However, most of the researches of TPD using reflection were done outside Indonesia.
In Indonesia, there are several pieces of research carried out in the scope of using reflection as TPD (Kuswandono, 2014; Sari, 2012). Yet, most of them focus on pre-service teachers. It is found to be a very effective tool in developing pre-service English teachers professionally. Thus, why not using it for in-service English teachers? As it has been described, English teachers in Indonesia are seeking for a tool that can accommodate the chatting and sharing of experience; reflection is one of the possible answers to it. Still, one question remains: what type of reflection?

CIT framework is one of the considered frameworks of reflection (Flanagan, 1954; Kain, 2003). It can be traced back to Flanagan (1954) in which he defined it as "a set of procedures for collecting direct observations of human behaviour in such a way as to facilitate their potential usefulness in solving practical problems and developing broad psychological principles" (para. 2). Kain (2003) further corroborates Flanagan's idea as "the critical incident technique provides a systematic means of gathering the significances others attach to events, analysing the emerging patterns, and laying out tentative conclusions for the reader's consideration" (p. 85). This framework focuses on the incident which happens on one's experience and "the meanings individuals make of events in their lives" (Kain, 2003). Thus, incident is a pivotal element in this framework in 
which it can be defined as an action and/or event that happens in one's life which brings either good or bad impact to one's life (Curtis et al., 2015; Flanagan, 1954; Hall \& Townsend, 2017; Kain, 2003). This incident can be critical if one reflects on it deeply as an effort to make it meaningful to one's life - a turning point (Flanagan, 1954; Hall \& Townsend, 2017). When it is critically reflected, it can and will become one's cornerstone which provides foundational footing for that someone for the rest of his/her life; which is the final aim of CIT framework.

For English teachers in Indonesia, this foundational footing will be very helpful for them in providing 'shelter' amidst the ever-changing English curriculum. Furthermore, this framework would help English teachers to internalize their own experience as most of the times, an experience would just be a mere experience if it is not internalized (Curtis et al., 2015). When it is internalized, though, an experience can strengthen and develop one's life meaningfully (Hall \& Townsend, 2017). This framework itself has been proven to be effective in developing English teachers professionally by many researchers (e.g. Chien, 2016; Hall \& Townsend, 2017). However, this framework is - according to the researchers' searches - not yet researched in the Indonesian context, especially for Indonesian English teachers.
In short, based on the background and literature above, this research intends to investigate reflection as a form of TPD in Indonesia. The reflection itself is based on CIT framework to incite the teachers' meaningful experiences. By using this framework, sharing professional experiences to elicit the meaningfulness within could be better facilitated. This framework has been found effective by a number of researchers (e.g. Bruster \& Peterson, 2013; Chien, 2016; Farrell, 2013; Hall \& Townsend, 2017). The researchers want to see whether using this framework for Indonesian English teachers would share similar strengths and effectiveness as its international counterpart. The research's objectives can be summarised into two research questions as follows: 1) What were the positive and negative CIs identified from the teachers' experience?; 2) How did those CIs develop teachers professionally?

Thus, this research invited six English teachers of a private school in Cirebon, Indonesia to critically reflect and share their most memorable incidents to make those incidents more meaningful and internalized for them.

\section{METHOD}

\section{Research design}

This research used narrative inquiry as the underlying method to accommodate the teachers' CIT reflection. The reasoning behind this is because human's life is composed by 
narratives and by inquiring narratives, social practice can be extracted (Alsup, 2006). It will be very powerful for teachers if the teachers can inquire about the narratives from within and reflect on them. This is corroborated by Farrell (2013) as "by telling their stories, teachers can not only reflect on specific incidents within their teaching world but also feel a sense of cathartic relief and it offers an outlet for tensions, feelings and frustrations about teaching" (p. 81). This method will accommodate the teachers to both vents their emotion (Chien, 2016) to others and reflect critically on their incidents (Farrell, 2013).

\section{Setting and participants}

The participants for this research were six English teachers from a private school located in Cirebon, Indonesia. These teachers consisted of two kindergartens (Anggi and Brie), two elementary (Ellis and Friska), and two junior high teachers (Castiel and Drini) and their demographic data are presented in Table 1. The consideration for this purposive sampling to choose all the English teachers in this school is to ensure the richness of the data. The six participants would show the varying CIs experienced by them and the effects of those CIs to their professional development as a teacher.

Table 1.Participant's demographic data

\begin{tabular}{llll}
\hline $\begin{array}{lll}\text { Pseudon } \\
\text { ym }\end{array}$ & Age & Gender & $\begin{array}{l}\text { Years in } \\
\text { teaching }\end{array}$ \\
\hline Anggi & $20-29$ & $\mathrm{~F}$ & 3 \\
Brie & $30-39$ & $\mathrm{~F}$ & 12 \\
Castiel & $40-49$ & $\mathrm{M}$ & 12 \\
Drini & $30-39$ & $\mathrm{~F}$ & 6 \\
Ellis & $30-39$ & $\mathrm{~F}$ & 20 \\
Friska & $40-49$ & $\mathrm{~F}$ & 21 \\
\hline
\end{tabular}

\section{Data collection and analysis}

Hughes (2007) states that one of the preferred data collection techniques for this CIT framework is an individual interview. Nevertheless, Flanagan (1954) emphasizes that CIT framework's data collection technique is not rigid; it must adapt to a certain context. In this research context, according to the initial data that the researcher gathered from informally talking to the participants, they did not understand about the critical incident. Thus, while the interview was still the main data collection technique, the researcher gave a pre-interview reflection that included the explanation of CIT and guiding questions to incite the participants' critical incident and for them to reflect on.

The guiding questions were not obligatory for the participants to answer but they were welcome to do so. Included in the guiding questions were wh- questions adapted from Farrell (2013) as he found that they were effective in inciting teacher's critical incident. After the researcher piloted the questionnaire and got a satisfying result, the researcher gave the questionnaire to 
each participant and explained it a bit. After that, a one-week period was given to the participants for them to reflect on their most critical incident as an incident can only be critical if it is reflected (Flanagan, 1954). In the next phase, the researcher interviewed the participants individually to explore the incidents and the effect of those incidents in developing the participants professionally, making those incidents critical.

From both the reflection and interview, two forms of teachers' critical incidents were gathered: the highest and lowest points of teaching. While the reflection tried to incite the teachers' critical incidents, the interview tried to delve into the depth of teachers' critical incident (Flanagan, 1954), especially in terms of the effects of the CIs to the teachers. From the interview, triangulated with the reflection, the researcher coded the data to find out the effects of CIs to them using open-, axial-, and selective coding.

\section{FINDINGS AND DISCUSSION}

\section{Findings of the teachers' CIs}

In this research, the participants shared their two most memorable CIs (positive and negative) during their teaching career that changed their view about teaching and learning processes through guided reflection and interview. Nevertheless, life is composed of many incidents (Körkkö et al., 2016). One that must be highlighted is that a teacher's
CI might be influenced by other CIs that he or she experienced (Farrell, 2013). Just like making sense of the narratives in one's life, CIs cannot be viewed as a separate entity. These CIs happened in one's life must be interwoven into a single, structured framework of life to make the most meaning of them.

One of the examples in this research is from Ellis. She experienced her negative CI because of her positive CI. As she found that her talent was in teaching from the positive $\mathrm{CI}$, she wanted to develop it even further. This led to her working in that private education institution and experiencing that negative CI. The meaningfulness of both CIs would be lower if viewed individually.

Therefore, in the discussion of the teachers' critical incident, the researcher did not limit it to only two critical incidents (positive and negative) from each participant. Other supportive critical incidents mentioned by the participants were used to corroborate and make sense of their main critical incidents. This led to a more fruitful and meaningful discussion between the researcher and the participants about the CIs and the process existed behind those CIs.

Teachers' professional development as seen through their critical incident reflection

From their CIs, discussion, and elaboration during the interview, five 
substantial themes were identified. The identification itself was based on the effect of the CIs to their life, especially on how they viewed themselves as a professional teacher. Four of those themes are teacher as a calling, teacher as a lifelong learner, teacher as a facilitator, and encouraging learning environment. The fifth theme is a special theme discussing the two most meaningful critical incidents identified from this research which ultimately changing oneself.

\section{Teacher as a calling}

One of the most notable excerpts for this part is "at that moment I felt that my choice to become a teacher was right" that Drini mentioned passionately when asked about her feeling in experiencing her positive $\mathrm{CI}$. Her $\mathrm{CI}$ strengthened her will in being a teacher (Bruster \& Peterson, 2013). This theme is what was extracted from all participants in reflecting their CIs.

Anggi, the youngest teacher in this research, believed that being a teacher meant being passionate and doing it by heart. This is corroborated by Drini in which she told that "teaching must be enjoyed". Thus, their CIs developed their teaching beliefs which in turn strengthened themselves in being a teacher.

While Anggi and Drini focused on the process of being a teacher,
Brie, Castiel, and Friska focused on the result that a teacher would get. Brie mentioned that "my personal satisfaction was that I had touched the students' life". This expression, according to Bruster and Peterson (2013, p. 177), is the final phase of the reflection in which the teacher contemplate on a deeper level - moral and ethical issues - and view teaching as a calling. For Brie, seeing her students succeeded in their life satisfied her and became the reason for her in continuing to be a teacher. Friska also had the same belief as Brie as "sometimes I felt proud, even though I was not the only factor". She shared that several students and parents thanked her personally because of the guidance. This became her motivation to keep being a teacher even after teaching for 21 years. After all, as Castiel mentioned, "teacher is a human, when we successfully direct, guide our students, it would increase teacher's confidence". By focusing on the concrete results in their students that happened because of them, they became more convinced in their choice to be a teacher (Palmer, 1998).

For Ellis in particular, she also mentioned almost the same thing as Drini in which "after several times teaching in a Sunday school, I finally realized that my talent was in teaching". Even though the effect 
was the same, both did not share the same CI. Drini got a letter that strengthened her will in being a teacher while for Ellis, her positive CI was the starting point for her in becoming a teacher. Ellis felt something different from her previous jobs; she felt the excitement that she could not find in her previous job. Ellis even mentioned that if she did not reflect on that incident critically, she would not be a teacher today.

This finding is in line with what Farrell (2013) found. In his research, the participant became more aware of herself as a teacher and her teaching through reflecting $\mathrm{CI}$; this strengthened her will in being a teacher. Thus, a well-reflected CI could show meaningfulness in being a teacher and make the teachers view their career as a calling.

\section{Teacher as a Lifelong Learner}

In their reflection of their CIs, Brie and Ellis mentioned that in the beginning, they never thought of being a teacher. Yet, now they became a good teacher. The reason behind it is because both of them, just like the other participants, believed that a teacher is a lifelong learner (Körkkö et al., 2016, p. 204).

In the case of Brie, when she was a novice teacher, she did not know about the theories thoroughly, she only used her instinct. She was teaching and learning at the same time. Though, by learning through her ups and downs - experience and observation - and by feeling it by herself, she was shaped into what she was now (Bruster \& Peterson, 2013).

Drini was also as inexperienced as Brie during her novice teaching. She tried to overcome it by teaching using the books provided. Yet, when she saw the results, she was not satisfied at all. From there, she learned to use several different methods that "in my opinion, at that moment, those methods were appropriate with the class' psychology". This shows her improvement in her teaching method. By always reflecting when she was teaching, she could learn to be a better teacher (Palmer, 1998).

This is emphasised by Castiel as "teaching means learning...the point is lifelong study, do not be satisfied quickly with what we have achieved now". Anggi further corroborates this as "I need to keep learning as a teacher no matter what". Both Castiel and Anggi emphasised heavily that when someone wants to be a teacher, he/she must also want to learn. This is because teaching is a complicated process that is ever-changing according to the era and a teacher is required to always keep up with it (Wiyono, 2017). Yet, 
a teacher is not an omnipotent being (Palmer, 1998). Friska stated that "I realized that I was not smart, but I would always keep trying to enable myself". She showed deliberate metacognitive thinking (Spruce \& Bol, 2015) which urged her to always learn and develop herself. This is a must-have quality for a teacher (Mansor et al., 2012; Postholm, 2012); not always being perfect, but being humble enough to know that he/she still needs to learn every single day. This is further illustrated by Palmer (1998, pp. 9-10) as he says that he is both a veteran and amateur teacher when entering a new class. It means that even though he already taught for thirty years, he always needed to learn strategies to cope with a new class; therefore, being a lifelong learner. In the end, as Ellis believed, "it is better for our students to learn from moving water than stagnant water"; affirming the importance of lifelong learning for a teacher.

\section{Teacher as a Facilitator}

Teaching now is more than just lecturing, it is about facilitating (Harden \& Crosby, 2000). This is corroborated by Farrell's (2016) finding in which the participants' beliefs were mainly about learner-centred growth in which a teacher must support and facilitate his/her students. This notion was critically reflected by all of the participants.
Anggi and Drini showed a strong tendency towards this belief as "now, a teacher is a facilitator" and "a teacher is not the omnipotent, a teacher is not the source of everything, my function is just a facilitator" respectively. Friska also supported this as she mentioned that "we can only become a facilitator; directing them, developing their character". She pointed out that her use of the personal approach to her students was effective as it could strengthen the teacher-student bond and develop the students' character.

Students' character becomes a major element to be developed by the teachers. This is strongly believed by Drini as "school is about developing character, if the students' character cannot be developed, going to school would be in vain". This is further corroborated by Friska as she mentioned that "a professional teacher not only transfers knowledge but also develops the students' character".

Furthermore, teacher as a facilitator means that "teaching is not just merely about giving knowledge anymore, it is more about giving the motivation" (Castiel). He mentioned that a teacher must be able to develop students' confidence by always giving them motivation. This is further corroborated by Brie and 
Ellis as they tried to motivate their students to love English and always be curious about it.

After all, the students would govern their own life and learning; a teacher could only do so much to support them to achieve that level. Thus, it is essential for a teacher to facilitate students' character development and eventually, their willingness and enthusiasm to learn. This notion is supported by Top, Liew, and Luo (2016) as they found that focusing on students' character development would increase their behaviours and also their academic achievement. After all, the students are humans. They need someone who can embrace and support them (Ellis). This is, ultimately, what a teacher as a facilitator is (Farrell, 2016; Grasha, 1994).

To conclude, some of the participants have taught for over 10 years, two even have taught for over 20 years. For them to be able to change their perception to follow the era is not an easy task. Yet, through critically reflecting from their past experiences, they could change themselves and develop this very important quality. This finding emphasises the importance of reflecting one's CIs.

\section{Encouraging learning environment}

The last theme extracted from the participants' CIs, especially from the CIs of Brie, Castiel, Drini, and Ellis is engaging more in making an encouraging learning environment. One of the possible ways of making this kind of environment, according to Castiel, is making the students feel secure in the class so that they would not be afraid. He further elaborated that "the students' ability in understanding learning material varies. The teachers need emotional stability to overcome that". By having a stable emotion, a teacher would be able to encourage students to practice more and learn from their mistakes.

The encouragement for the students to practice more and not to be afraid of making mistakes is critically needed, especially in the language class (Al Azri \& Al-Rashdi, 2014). This is what Brie and Castiel believed as they gave more space to the students to practice. Brie pointed out that "the portion for the students to speak must be higher than structure and writing". Castiel agreed with Brie's point as he stated that "the point is the balance between theories and practice, that is what I prioritize". One of the underlying reasons for him to do this is that during his school time, he observed that the students who could achieve high scores also demonstrated good speaking skills. He then recalled his experience during the English day occurring two times a week. It was 
a day in which the students must speak English throughout the day. As he reflected critically, he concluded that it was because of practice, those students were able to attain a good level in speaking. Therefore, he focused on developing an environment that could nurture his students' confidence in speaking English; essentially, a place for his students to practice and make a mistake. The importance of practice is highlighted by $\mathrm{Al}$ Azri and Al-Rashdi (2014) as they believe that accommodating the students with the authentic environment for the students to practice would increase the students' ability significantly.

\section{Another}

kind

of encouragement that the teachers gave is motivation. Brie was startled as when she gave positive feedback to one of her students, that student became more focused on the teaching and learning processes and more confident in himself. Drini and Ellis also experienced this. When they motivated their students, the students showed a substantial improvement, especially in their willingness to learn English.

In the end, the teachers are the foundation in the making of an encouraging learning environment. The teachers must first be able to regulate themselves. Drini supported this as she believed that a teacher must first enjoy the teaching and learning process. If not, "stressful teachers tend to create stressful students" (Drini). This is corroborated by Castiel as he believed that a teacher must be able to create a comfortable environment for the students to learn and enjoy the class.

\section{Becoming the true-self: Unique cases}

Besides those five themes identified, there are two unique cases needed to be scrutinized without any name mentioned. The first case occurred when a parent misunderstood the teacher's classroom management treatment as the students' detention. This is a traumatizing event for the teacher since the children's parents could not tolerate the treatment even though it was given for the good of the children. This traumatic event was still imprinted in this teacher's memory until now. Thus, the teacher did a more preventive measure to not let this event happen again. While preventive measure might be helpful, the teacher was also aware that there was a small tendency to play safe and stay aloof from the students who were misbehaving.

Another case from one of the teachers is because of a traumatizing event, the teacher 
changed drastically. In the beginning, the teacher wanted to please everyone. However, because of a sudden traumatizing incident, the teacher changed. Even the closest people believed that this teacher underwent a total change. This teacher became more confident and assertive. While this was a good change, there was a small tendency that this teacher became disinterested with other's opinion.

It is apparent that the accumulation of one's CIs, either positive or negative, would change his/her behaviour in his/her daily life. As seen from both cases, the negative CIs in the form of a traumatizing event would have a stronger effect in changing one's life, albeit a somewhat negative effect. This has been researched by McGarr and McCormack (2016) in which they found that the participants tended to focus on negative CIs and made counterfactual thinking. This shows that personal bias might exist in reflecting own CIs. Hence, the moral support from other people is needed to ensure the change is a positive one (Farrell, 2013) as 'two heads are better than one'. Having a place for them to share their stories would lead to a different change in their life. Other people's opinion would help them in deciding what to do next; this is the importance of sharing one's CIs.
Furthermore, by reflecting one's CIs, the teachers are invited to make sense of their experiences using language and share them with other people. This notion is summed up in Bahk's (2018) powerful statement in which "using language to represent stress, and conflict, and anger, and joy, and finding the deeper meaning underlying those experiences which is, I think, one of the most powerful ways that we find happiness" (00:18:50 - 00:19:03). Thus, making sense of one's CIs and life through words with either oneself or others would lead to a wholesome life.

\section{CONCLUSION AND SUGGESTION}

As seen through the discussion, CIs gathered from the teachers had an impact on their lives, especially their teaching career. Five impacts are coded from the teacher's reflection and interview: teacher as a calling, teacher as a lifelong learner, teacher as a facilitator, the importance of communication and students' character development, and encouraging learning environment. It can be inferred that as those CIs happened, particularly for the positive CIs, the teachers became more convinced in being a teacher and developing themselves to be a good teacher. If those CIs are reflected well, especially like in Ellis' case, CIs can become a major life-changing force. 
Nevertheless, negative CIs must also be acknowledged. As seen through the special cases, if negative CIs are reflected only from one's perspective, it might be falsely interpreted. Thus, it is very crucial for the CIs to be shared and scrutinized together with other people.

All in all, reflecting CIs is very important as those CIs would become a strong foundation for someone's life make or break one's life. The reason is that by telling and reflecting CIs, a more in-depth understanding of one's life could be achieved. Through a deep understanding of one's life, the teachers would be able to develop themselves to the fullest. Thus, reflecting CIs is an integral part of one's life.

As both positive and negative CIs can be a double-edged sword when viewed from only one's perspective, other people's perspective must also be invited and acknowledged to make the CIs neutral and meaningful. Furthermore, all the people have reflected on their experience to a certain degree. Yet, each person has a different ability in reflection. Therefore, the reflection of the CIs is best to be done with colleagues to avoid personal bias; this is called critical friendship. This notion needs further investigation, especially in the context of Indonesia.

Additionally, there are two research limitations acknowledged. The first limitation is that the researcher only gathered the teachers' CIs without giving meaningful feedback to the teachers due to the researcher's position. The second one is the teachers only reflected their CIs once. Therefore, it is suggested that future researchers must be in the position to guide the teachers in reflecting their CIs for several times personally and in a group.

\section{REFERENCES}

Al Azri, R. H., \& Al-Rashdi, M. H. (2014). The effect of using authentic materials in teaching. International Journal of Scientific $\mathcal{E}$ Technology Research, 3(10), 249-254.

Alsup, J. (2006). Teacher identity discourses: Negotiating personal and professional spaces. Mahwah, NJ: Erlbaum.

https://doi.org/10.4324/9781410 617286

Bahk, J. (Producer). (2018, June 28). Episode 14: What are you afraid of? [Audio podcast]. Retrieved from https://greatergood.berkeley.edu /podcasts/item/what_are_you_af raid_of

Bruster, B. G., \& Peterson, B. R. (2013). Using critical incidents in teaching to promote reflective practice. Reflective Practice, 14(2), 170-182. https://doi.org/10.1080/1462394 3.2012.732945

Chien, C. W. (2016). Analysis of design and delivery of critical incident workshops for elementary school English as a foreign language 
teachers in community of practice. International Journal of Primary, Elementary and Early Years Education, 1-15.

https://doi.org/10.1080/0300427 9.2016.1163400

Curtis, E., Wikaire, E., Kool, B., Honey, M., Kelly, F., Poole, P., ... Reid, P. (2015). What helps and hinders indigenous student success in higher education health programmes: a qualitative study using the Critical Incident Technique. Higher Education Research \& Development, 34(3), 486-500.

https://doi.org/10.1080/0729436 0.2014 .973378

Farrell, T. S. C. (2013). Critical incident analysis through narrative reflective practice: a case study. Iranian Journal of Language Teaching Research, 1(1), 79-89. Retrieved from www.urmia.ac.ir/ijltr

Farrell, T. S. C. (2016). The teacher is a facilitator: Reflecting on ESL teacher beliefs through metaphor analysis. Iranian Journal of Language Teaching Research, 4(1), 1-10. Retrieved from www.urmia.ac.ir/ijltr

Flanagan, J. C. (1954). The critical incident technique. Psychological Bulletin, 51(4), 327-358. https://doi.org/10.1037/h006147 0
Golombek, P., \& Doran, M. (2014). Unifying cognition, emotion, and activity in language teacher professional development. Teaching and Teacher Education, 39, 102-111.

https://doi.org/10.1016/j.tate.201 4.01 .002

Grasha, A. F. (1994). A matter of style: The teacher as expert, formal authority, personal model, facilitator, and delegator. College Teaching, 42(4), 142-149. https://doi.org/10.1037/024767

Hall, J. M., \& Townsend, S. D. C. (2017). Using critical incidents and E-Portfolios to understand the emergent practice of Japanese student-teachers of English. Teaching and Teacher Education, 62, 1-9.

https://doi.org/10.1016/j.tate.201 6.10.017

Harden, R. M., \& Crosby, J. (2000). AMEE guide no 20: The good teacher is more than a lecturerĐ the twelve roles of the teacher. Medical Teacher, 22(4), 334-347. https://doi.org/10.1021/ct200074 c

Hawanti, S. (2014). Implementing Indonesia's English language teaching policy in primary schools: The role of teachers; knowledge and beliefs. International Journal of Pedagogies and Learning, 9(2), 162-170. 
https://doi.org/10.1080/1833410 5.2014.11082029

Hughes, H. (2007). Critical incident technique. In S. Lipu, K. Williamson, \& A. Lloyd (Eds.), Exploring Methods in Information Literacy Research. Topics in Australasian Library and Information Studies (pp. 49-66). Wagga Wagga, N.S.W.: Centre for Information Study, Charles State University. https://doi.org/10.4135/9781412 963909

Kain, D. L. (2003). Owning significance: The critical incident technique in research. In K. DeMarrais \& S. D. Lapan (Eds.), Foundations for Research: Methods of Inquiry in Education and the Social Sciences (pp. 69-85). Mahwah, NJ, NJ: Lawrence Erlbaum Associates. https://doi.org/10.4324/9781410 609373

Kelly, J., \& Cherkowski, S. (2015). Collaboration, collegiality, and collective reflection: A case study of professional development for teachers. Canadian Journal of Educational Administration and Policy, 169, 1-27.

Killeavy, M., \& Moloney, A. (2010). Reflection in a social space: Can blogging support reflective practice for beginning teachers? Teaching and Teacher Education, 26(4), 1070-1076. https://doi.org/10.1016/j.tate.200 9.11.002
Körkkö, M., Kyrö-Ämmälä, O., \& Turunen, T. (2016). Professional development through reflection in teacher education. Teaching and Teacher Education, 55, 198-206. https://doi.org/10.1016/j.tate.201 6.01 .014

Kuswandono, P. (2014). Voices of Pre-Service English Teachers: Reflecting Motivations During Practicum Learning. TEFLIN Journal: A Publication on Teaching and Learning of English, 25(2), 185-202.

https:// doi.org/10.15639/TEFLI
NJOURNAL.V25I2/185-202

Mansor, A. N., Eng, W. K., Rasul, M. S., Izham, M., Hamzah, M., \& Hamid, A. H. A. (2012). Effective Classroom Management, 5(5), 35-42.

https://doi.org/10.5539/ies.v5n5 p35

Marcellino, M. (2008). English language teaching in Indonesia: A continuous challenge in education and cultural diversity. TEFLIN Journal: A Publication on the Teaching and Learning of English, 19(1), 57-69. https://doi.org/10.15639/TEFLI NJOURNAL.V19I1/57-69

McGarr, O., \& McCormack, O. (2016). Counterfactual mutation of critical classroom incidents: Implications for reflective practice in initial teacher education. European Journal of Teacher Education, 39(1), 
36-52.

https://doi.org/10.1080/0261976

8.2015.1066329

Mustofa. (2007). Upaya pengembangan profesionalisme guru di Indonesia. Jurnal Ekonomi \& Pendidikan, 4(April), 62-75.

Nauman, S. (2017). Applying and evaluating teacher professional development models - A case study of a Pakistani school. International Journal of Experiential Learning $\mathcal{E}$ Case Studies, 2(2), 20-33.

Palmer, P. J. (1998). The courage to teach: Exploring the inner landscape of a teacher's life (1st ed.). Hoboken, NJ: John Wiley \& Sons, Inc.

Patton, K., Parker, M., \& Pratt, E. (2013). Meaningful learning in professional development: Teaching without telling. Journal of Teaching in Physical Education, 32(4), 441-459. https://doi.org/10.1123/jtpe.32.4. 441

Postholm, M. B. (2012). Teachers' professional development: A theoretical review. Educational Research, 54(4), 405-429. https://doi.org/10.1080/0013188 1.2012 .734725

Putri, A. D. K., \& Imaniyati, N. (2017). Professional development of teachers in imporving the performance of teacher. Jurnal
Pendidikan Manajemen Perkantoran, 1(1), 94-103.

Rahman, A. (2016). Teacher professional development in Indonesia: The influences of learning activities, teacher characteristics and school conditions. University of Wollongong. Retrieved from http://ro.uow.edu.au/theses / \%0 A4721

Sari, E. R. (2012). Online learning community: A case study of teacher professional development in Indonesia. Intercultural Education, 23(1), 63-72. https://doi.org/10.1080/1467598 6.2012.664755

Spruce, R., \& Bol, L. (2015). Teacher beliefs, knowledge, and practice of self-regulated learning. Metacognition and Learning, 10(2), 245-277.

https:/ / doi.org/10.1007/s11409-0 14-9124-0

Top, N., Liew, J., \& Luo, W. (2016). Effects of second step curriculum on behavioral and academic outcomes in 5th and 8th grade students: A longitudinal study on character development. Novitas-ROYAL, 10(1), 24-47.

Varghese, M., Morgan, B., Johnston, B., \& Johnson, K. A. (2005). Theorizing language teacher identity: Three perspectives and beyond. Journal of Language, Identity and Education, 4(1), 21-44. 
https://doi.org/10.1207/s1532770 1jlie0401

Widodo, A., \& Riandi. (2013).

Dual-mode teacher professional development: Challenges and re-visioning future TPD in Indonesia. Teacher Development, 17(3), 380-392. https://doi.org/10.1080/1366453 0.2013 .813757

Wiyono, S. (2017). The 21st century: The turning point of the English language teaching in Indonesia.
KnE Social Sciences, 1(3), 303. https://doi.org/10.18502/kss.v1i 3.750

Yuwono, G. I., \& Harbon, L. (2010). English teacher professionalism and professional development: Some common issues in Indonesia. Asian EFL Journal, 12(3), 145-163. Retrieved from http://ezproxy.scu.edu.au/login? url=http:// search.ebscohost.com/ login.aspx?direct=true $\& \mathrm{db}=\mathrm{ehh} \&$ AN $=56441736 \&$ site $=$ ehost-live . 